\title{
RELEVANSI NILAI AKUNTANSI, NILAI BUKU DAN LABA DARI SEBAGAI DASAR PENGAMBILAN KEPUTUSAN BERINVESTASI
}

\author{
M. Ali Fikri \\ Universitas Mataram \\ fikri.sampala@unram.ac.id \\ Eni Indriani \\ Universitas Mataram \\ eni.indriani@unram.ac.id \\ Yusli Mariadi \\ Universitas Mataram \\ yuslimariadi@unram.ac.id \\ Disubmit : 15 Februari 2021 \\ Direview : 28 Oktober 2021 \\ Diterima : 16 Desember 2021
}

\begin{abstract}
This study explains firm value relevance using the profit and book value approach, due to the phenomenon declining quality of accounting information in the capital market. Respondent of this research using lecturers, practitioners, and capital market players who have made transactions in the capital market using a qualitative approach. The results of the study that the profit and balance sheet approach has a small impact on changes in stock prices. Investors expect a return form cash flow and technical analysis.
\end{abstract}

Key Words: book value; income; cash flow

\begin{abstract}
Abstrak
Penelitian ini menjelaskan hubungan relevansi nilai perusahaan menggunakan pendekatan laba dan nilai buku, karena fenomena menurunnya kualitas informasi akutansi di pasar modal. Penelitian ini dilakukan di sekitar ruang lingkup dosen, praktisi, dan pelaku pasar modal yang telah melakukan transaksi di pasar modal menggunakan pendekatan kualitatif. Hasil penelitian secara umum menyatakan bahwa pendekatan laba dan Neraca memiliki dampak kecil terhadap perubahan harga saham. Investor lebih mengharapkan return berupa kas atau melalui analisis teknikal.
\end{abstract}

Kata Kunci: nilai buku; nilai laba; arus kas

\section{PENDAHULUAN}

Penelitian relevansi nilai merupakan penelitian akuntansi berbasis pasar modal (Beaver 2002). Penelitian ini berawal dari hasil penelitian Ball dan Brown tahun 1968 (Francis dan Schipper, 1999) melalui pengujian kegunaan informasi laba akuntansi terhadap abnormal return pasar modal. Relevansi nilai merupakan penjelas informasi angka akuntansi, terutama laba dan nilai buku terhadap sekuritas. Apakah angka akuntansi memiliki nilai bagi investor, dan apakah akuntansi merupakan nilai yang relevan menjelaskan harga di pasar modal. 
Penelitian relevansi nilai secara spesifik melakukan pengujian asosiasi antara variabel harga sekuritas dan variabel informasi akuntansi. Akuntansi dianggap memiliki nilai relevan jika saling berhubungan. Relevansi nilai didasarkan argumen tentang akuntansi berhubungan dengan nilai pasar ekuitas (Beaver, 2002). Secara umum relevansi nilai Hmenggunakan pendekatan nilai buku dan laba akuntansi.

Ketersediaan informasi yang disajikan akan direspon investor untuk menilai kinerja perusahaan (Subramanyam, 1996; Beaver, 2002). Penelitian relevansi nilai (Jones, 1991; Ohlson, 1995; Dechow et al., 1995; Burgstahler dan Dichev, 1997; Francis dan Schipper, 1999; Barth et al., 1999; Marquardt dan Wiedman 2004) menyatakan relevansi nilai bergantung dari kualitas informasi yang tersedia. Permasalahan berhubungan dengan relevansi nilai, apakah kualitas informasi yang disajikan sesuai kondisi perusahaan sesungguhnya.

Kualitas informasi dan akses informasi internal dan prospek perusahaan di masa mendatang yang dimiliki lebih banyak oleh manajemen dibandingkan investor dapat menimbulkan asimetri informasi. Kondisi ini dapat mendorong manajemen berperilaku opportunistic dan memilih kebijakan akuntansi sesuai dengan kepentingannya, di samping standar akuntansi memberikan fleksibilitas kebijakan jika kinerja manajemen diukur berdasarkan laba (Healy, 1985). Perilaku disfunctional behaviour ini disebut sebagai perilaku manajemen laba.

Konsekuensi manajemen laba ini, yaitu investor tidak bisa menyandarkan diri sepenuhnya pada informasi yang disajikan untuk mengukur kinerja perusahaan (Marquardt dan Wiedman, 2004). Untuk menjamin ketersediaan informasi yang lebih baik, pihak investor berusaha mencari metode alternatif lain mengukur kinerja perusahaan.

Ohlson (1995), Solomon (1995), Brugstahler dan Dichev, (1997), Collins et al. (1997), Francis dan Schipper (1999), Barth et al. (1999), Beaver (2002), dan Marquardt dan Wiedman (2004) menyatakan terdapat dua cara pengukuran umum yang digunakan investor untuk menentukan nilai infomasi akuntansi, yaitu pendekatan rugi laba dan pendekatan neraca. Pendekatan rugi laba diukur berdasarkan nilai laba sedangkan pendekatan neraca diukur berdasarkan nilai buku. Meskipun demikian, terdapat pertentangan tentang relevansi nilai berdasarkan pendekatan laba dan nilai buku (Solomons, 1995). Solomons (1995) menyatakan pendekatan neraca lebih berguna menilai perusahaan dibandingkan pendekatan laba karena menggambarkan kondisi sumber daya perusahaan dengan lebih tepat. Barth dan Landsman (1995) menyatakan dalam pasar yang sempurna, fair value accounting based balance sheet lebih menyajikan seluruh informasi yang relevan, sedangkan laporan laba rugi memberikan informasi yang terlalu berlebihan dan realisasi laporan laba rugi yang tidak relevan. Brugstahler dan Dichev (1997), Francis dan Schipper (1999), dan DeFond (2002) menyatakan pendekatan nilai buku lebih dipercaya oleh pihak investor dibandingkan dengan pendekatan laba dengan alasan laba memberikan informasi operasi perusahaan per periode, sedangkan nilai buku memberikan informasi nilai bersih sumber daya perusahaan jangka panjang.

Penelitian ini merupakan pengembangan studi sebelumnya yang dilakukan oleh Bruhstahler dan Dichev (1997), Collins et al. (1997), Rangan (1998), Teoh et al. (1998), Francis dan Shipper (1999), Barth et al. (1999), Lev dan Zarrowin (1999), Dontoh et al., (2004), dan Marquardt dan Weidman (2004) yang menjelaskan hubungan oportunisasi manajemen laba, informasi akuntansi, dan relevansi nilai. Studi menjelaskan hubungan relevansi nilai perusahaan menggunakan pendekatan laba dan nilai buku. 


\section{METODE PENELITIAN}

Penelitian ini merupakan penelitian dengan menggunakan pendekatan deskriftif. Analisis deskriftif dimaksudkan untuk menggambarkan fenomena yang terjadi di lapangan menggunakan data wawancara dari tenaga ahli yang bergelut di bidang akuntansi maupun pasar modal. Lokasi penelitian dilakukan di lingkungan Universitas Mataram dengan alasan Universitas sebagai sarana untuk pengajaran mata kuliah pasar modal dan di lingkungan luar Universitas Mataram seperti akuntan berpraktek di kota Mataram maupun tenaga ahli dari lembaga profesional IAI Wilayah NTB.

Hampir sama dengan metode penelitian lainnya, penelitian ini menggunakan serangkaian proses dan teknik untuk melakukan penggalaian data di lapangan. Kehadiran peneliti untuk berinteraksi dengan subjek diharapkan memberi pemahaman lebih utuh penelitian melalui wawancara partisipan untuk melihat secara langsung perilaku yang berhubungan dengan fenomena yang diamati (Sanders, 1982, Saerang, 2001, 87). Penggalian data di lapangan peneliti lakukan dengan cara teknik analisis wawancara kepada tenaga pengajar (dosen) yang berkecimpung dalam mata kuliah Pasar Modal, Akuntan Berpraktek/konsultan, dan anggota IAI Wilayah NTB.

\section{HASIL DAN PEMBAHASAN}

Responden penelitian dosen akuntansi menyatakan secara alami kedua pendekatan merupakan pendekatan yang sama. Bagi pelaku yang memahami laporan keuangan, pelaku pasti akan menggunakan kedua pendekatan, baik neraca dan laba rugi, karena keduanya tidak bisa dipisahkan.

Laba hanya perdiksi sementara, sedangkan neraca merupakan komponen menyeluruh. Pada ujungnya laba akan dikapitalisasi dalam neraca, sebagaimana dinyatakan oleh dosen pengampu mata kuliah pasar modal.

"secara teori ada beberpa penelitian yang menyatakan terjadi penurunan nilai relevansi akuntansi. Namun, penurunan itu masih sulit dibedakan apakah berdasarkan pendekatan laba rugi atau pendekatan neraca. Kedua pendekatan sama. Intinya adalah pada jumlah laba ditahan, apakah cukup dibagi atau tidak. Laba hanya sebagai prediksi saja, faktanya neraca yang banyak memiliki peran."

"tidak ada perbedaan antara keduanya. Penurunan relevansi nilai kebanyakan deisebabkan oleh faktor lain selain akuntansi"

Responden pengamat menyatakan sudah sifat menusia memperoleh keuntungan, tetapi perlu diingat, laba yang dimaksud adalah bukan laba accrual, tapi laba berbentuk kas. Semua sumber ekonomi digerakkan oleh kas, bukan akuntansi. Akuntansi hanya sebagai media catat mencatat. Faktanya di lapangan semua membutuhkan kas.

"yang terpenting adalah arus kas, bukan laba atau neraca. Investor membutuhkan kas, bukan piutang."

“terlalu banyak kasus accrual dalam akutansi, sejak kasus Enron, kepercayaan akan accrual menurun. Apalagi ditambah dengan kasus laporan keuangan Garuda."

Sejumlah responden Akuntan berpraktek menyatakan sumber ekonomi digerakkan oleh kas, bukan akuntansi.

"arus kas adalah faktor utama." 
"Investor nggak pernah lihat laba atau neraca, yang banyak dilihat prospek pasar dan trend harga saham. Pasar susah seperti ini banyak terjadi trend harga turun

"Jika saya malah bukan ketiganya. Penyebab membeli saham itu karena sayang uang mengnggur atau karena rayu broker"

dan responden pelaku pasar modal menyatakan:

"Mungkin bunkan laba atau neraca, tapi rasio keuangan, PER dan PBV, utk lihat kemurahan atau kemahalan"

Beberapa hasil wawancara mengenai Relevansi sebgai kekuatan penjelas secara menyeluruh dari informasi akuntansi terhadap harga saham mendukung sekaligus menolak beberapa hasil penelitian sebelumnya, seperti Brugstahler dan Dichev (1997), Barth et al. (1999), Rangan (1998), Francis dan Schipper (1999), Teoh et al. (1998), Dontoh et al. (2004), dan Marquardt dan Wiedman (2004) yang menemukan nilai variabel laba berpengaruh terhadap perubahan harga saham, namun mendukung penelitian Collins et al. (1997) yang menyatakan kombinasi relevansi nilai berdasarkan pendekatan laba dan nilai buku tidak mengalami berpengaruh terhadap penilaian investor.

Hasil penelitian ini memiliki temuan yang hampir sama dengan hasil penelitian sebelumnya, yaitu terjadi kesimpang siuran, yaitu laba dan nilai buku dapat berpengaruh dan tidak berpengaruh terhadap relevansi nilai. Meskipun secara umum temuan bebrapa penelitian tersebut, yiatu terjadi penurunan relevansi nilai informasi akuntansi.

Penjelas yang paling spesifik yaitu adalah masalah kas yang diterima di masa mendatang dan besaran penerimaan return.

\section{SIMPULAN}

Hasil penelitian secara umum menyatakan bahwa pendekatan laba dan Neraca memiliki dampak kecil terhadap perubahan harga saham. Penelitian ini dilakukan di sekitar ruang lingkup dosen, praktisi, dan pelaku pasar modal dengan jumlah sampel yang tidak banyak. Namun demikian pemilihan sampel ini dilakukan dengan menggunakan masukan dan saran dari responden yang telah berpengalaman dalam transaksi dan pengelolaan pasar modal. Selanjutnya diharapkan responden dapat diperbanyak dengan menggunakan pihak penerima keuntuangan atas transaksi sehingga terlihat kejelasan yang lebih baik kegunaan dari laporan keuangan di pasar modal.

Penelitian ini memiliki beberapa implikasi. Pertama, secara teoritis penelitian ini memberikan gambaran secara umum bahwa kas lebih bermakna terhadap prediksi return saham. Kedua, secara praktis dapat sebagai masukan bagi pelaku pasar modal dalam mengambil keputusan, dan Ketiga, hasil ini memiliki impikasi bagi pengambil kebijakan, bahwa kepastian return terutama kas/arus kas merupakan hal yang harus dijelaskan dalam laporan keuangan.

\section{DAFTAR PUSTAKA}

Ball, R. and P. Brown.1968. An Empirical Evaluation of Accounting Income Numbers. Journal of Accounting Research. Vol. 6 (Autumn). pp. 159-178

Barth, M.E., and WR Landsman. 1995. Fundamental Issues Related to Using Fair Value Accounting for Financial Reporting. Accounting Horizon. Vol. 9 No. 4. pp. 97-107.

Barth, ME., John A. Elliot, and Mark W. Finn. 1999. Market Rewards Associated With pattern on Increasing Earning. Journal of Accounting Research. Vol. 2 (Autumn). pp. 387-413. 
Beaver, William H. 2002. Perspectives on Recent Capital Market Research. The Accounting Review. Vol 7 (2) April. pp. 453-474.

Burgstahler, D. and I. Dichev, 1997, Earning, Adaption, and Equity Value, The Accounting Review, vol 72 pp187-215.

Collins, Daniel W., Edward L. Maydew, and Ira S. Weiss. 1997. Changes in the Value Relevance of Laba and Book Values Over the Past Forty Years. Journal of Accounting and Economics. Vol. 24. pp. 39-67.

Dechow, P, R. Sloan and Sweeney, 1995. Detecting Earning Management. The Accounting Review. Vol 70 pp.193-226.

DeFond, Mark L., 2002. Discussion of the Balance Sheet as an Laba Management Constraint. The Accounting Review. Vol 77 pp.29-33.

Dontoh, Alex., Suresh Radhakrishnan and Joshua Ronen. 2004. The Declining Value Relevance of Accounting Information and Non-Information-Based Trading: An Empirical Analysis. Contemporary Accounting Research. Vol. 21 pp. 793-812.

Francis, Jennifer and Catherine Schipper. 1999. Have Financial Statements Lost Their Relevance. Journal of Accounting Research. Vol. 37 (2). pp. 319-352.

Healy, P., 1985. The The Impact of Bonus Scheme on Selection of Accounting Principles. Journal of Accounting and Economic.

Jones, Jeniffer J. 1991. Earning Management During Import Relief Investigation. Journal of Accounting Research, Vol 29 No 2 Autumn.

Lev, Baruch and Paul Zarowin. 1999. The Boundaries of Financial Reporting and How To Extend Them. Journal of Accounting Research. Vol. 37 (2). pp. 353-385.

Marquardt, Carol A. dan Christine I. Weidman, 2004. The Effect Of Earning Management On Value Relevance Of Accounting Information. Journal of Business Finance and Accounting.

Ohlson, James A. 1995. Income, Book Values, and Dividen in Equity Valuation. Contemporary Accounting Research, Vol 11 No 2 Spring.

Scott, William R. 2003, Financial Accounting Theory, Pearson Education Canada Inc., Toronto, Ontario.

Subramanyam, K. R., 1996. The Pricing of Discretionary Accrual. Journal of Accounting and Economic. Vol 22 pp. 249-281.

Saerang, David Paul Elia (2001). Accountability and Accounting in a Religius Organization: an Interactive Ethnographic Study of the Pantecostal Chruch of Indonesia. Disertation University Wollonggong.

Sanders, Patricia (1982). Phenomenology: A New Way of Viewing Organizational Research. Academy of Management Review. Vol. 7 (3) pp 353-360.

Teoh Siew Hong, Ivo Welch, and T.J. Wong. 1998. Earning Management and the Underperformance of Seasoned Equity Offering. Journal of Financial Economic. Vol 50 pp.63-99. 